\title{
Intelegensi: Konsep dan Pengukurannya
}

\author{
Purwanto \\ STAIN Surakarta
}

\begin{abstract}
Abstrak: Intelegensi merupakan kemampuan yang bersifat umum dan potensial. Para ahli tidak mencapai kesepakatan dalam banyak hal mengenai intelegensi. Definisi-definisi yang dikemukakan menunjukkan batasan yang tidak serupa. Mereka juga tidak sepaham dalam melihat apakah intelegensi merupakan heriditas atau modifikasi. Beberapa mencoba menghubungkan intelegensi dengan bakat, kreativitas, dan prestasi. Para ahli juga berbeda dalam melihat komponen-komponen yang terdapat dalam intelegensi. Hal itu tampak dalam teori-teori yang mereka ajukan. Beberapa ahli yang mengajukan teorinya mengenai intelegensi, di antaranya adalah Terman, Spearman, Sternberg, Thurstone, Guilford, dan Gardner. Intelegensi diukur menggunakan tes intelegensi dan diskala menggunakan ukuran yang dikenal dengan IQ. Skor IQ diinterpretasikan dengan membandingkan IQ seseorang dengan kelompok sebaya atau kelompok norma.
\end{abstract}

Kata kunci: kemampuan, potensial, teori intelegensi, IQ, dan kelompok sebaya.

\begin{abstract}
Intelligence is a common and potential capability. Theorist have not agreed in its concept yet. Their definitions are not identical. They also do not agree with factors which contribute to intelligence. They try to correlate intelligence with talent, creativity and achievement. Their theories contain different elements. Some theorist are Lewis Terman, Charles Spearman, Sternberg, Louis Thurstone, James $\mathrm{P}$ Guilford and Howard Gardner. Intelligence is measured by a test and scaled in IQ. IQ score is interpreted by comparing one's IQ with his peer or norm group.
\end{abstract}

Key words : capability, potential, intelligence theory, IQ, and peer group.

\section{Pendahuluan}

Istilah inteligensi sangat akrab dalam dunia pendidikan dan pembelajaran. Hal ini disebabkan karena pendidikan dihadapkan pada anak-anak dengan berbagai kemampuan inteligensi. Pendidik harus memahami keragaman inteligensi anak didik. Pemahaman keragaman diperlukan untuk dapat memberikan layanan yang tepat untuk mencapai tujuan pendidikan.

Manusia dapat mempertahakan kelangsungan hidup dan mengembangkan diri karena mempunyai sejumlah kemampuan. Menurut Sukmadinata (2003 : 92), kemampuan atau kecakapan dapat dibagi menjadi dua. Pertama, kecakapan potensial (potential ability) atau kapasitas (capacity). Kecakapan potensial merupakan kecakapan yang masih tersembunyi, belum termanifestasikan dan dibawa dari kelahirannya. Kecakapan ini dapat dibagi menjadi dua yaitu inteligensi (intelligence) dan bakat (aptitude). Inteligensi merupakan kapasitas umum, sedang bakat merupakan kapasitas khusus. Kedua, kecakapan nyata (actual ability) atau prestasi (achievement). Kecakapan nyata merupakan kecakapan yang sudah terbuka, termanifestasikan dalam berbagai aspek kehidupan dan perilaku. Kecakapan ini berpangkal pada kecakapan potensial. Kecakapan terbentuk karena pengaruh lingkungan.

Inteligensi merupakan salah satu kemampuan manusia. Kemampuan inteligensi bersifat potensial dan merupakan kecakapan umum. Kecakapan ini dapat terwujud menjadi kecakapan nyata karena bantuan lingkungan.

Meski inteligensi sangat penting dalam pendidikan, rentang pemahaman mengenai konsep ini sangat bervariasi. Akibatnya timbul perdebatan konsep inteligensi dalam pelaksanaan pendidikan. Tulisan ini membuat kajian teoritik mengenai inteligensi, khususnya inteligensi sebagai kemampuan intelektual. Kajian berangkat dari masalah: 1) Bagaimana konsep inteligensi? 2) Apakah inteligensi merupakan heridititas atau modifikasi? 3) Bagaimana hubungan inteligensi dengan bakat, kreativitas dan prestasi? 4) Bagaimana perkembangan teori inteligensi? dan 
5) Bagaimana melakukan pengukuran inteligensi? Oleh karenanya tujuan kajian ini adalah untuk mengetahui: 1) konsep inteligensi, 2) inteligensi merupakan heriditas atau modifikasi, 3) hubungan inteligensi dengan bakat, kreativitas dan prestasi, 4) perkembangan teori inteligensi, 5) cara melakukan pengukuran inteligensi.

\section{Kajian Literatur}

\section{Pengertian inteligensi}

Para ahli belum sepakat mengenai berbagai hal tentang inteligensi. Konsensus mengenai arti inteligensi hampir tidak mungkin. Tahun 1921 diadakan simposium tentang inteligensi yang dilaporkan dalam Journal of Educational Psychology. Dari 12 orang psikolog yang diminta pandangannya, terdapat 12 pandangan yang berbeda (Woolfolk dan Nicolich, 1984 : 130).

Dalam hal definisi, terdapat banyak definisi yang dikemukakan oleh para ahli dengan beberapa variasi perbedaan. Definisi Thornburg, Freeman dan Robinson \& Robinson mempunyai banyak kesamaan. Menurut Thornburg (1984 : 179), inteligensi adalah ukuran bagaimana individu berperilaku. Inteligensi diukur dengan perilaku individu, interaksi interpersonal dan prestasi. Inteligensi dapat didefinisikan dengan beragam cara: (1) kemampuan berpikir abstrak, (2) kemampuan mempertimbangkan, memahami dan menalar, (3) kemampuan beradaptasi dengan lingkungan, dan (4) kemampuan total individu untuk bertindak dengan sengaja dan secara rasional dalam lingkungan. Menurut Freeman (Abror, 1993:43), inteligensi mempunyai pengertian: 1) inteligensi adalah adaptasi atau penyesuaian individu dengan keseluruhan lingkungan, 2) inteligensi adalah kemampuan untuk belajar, dan 3) inteligensi adalah kemampuan berpikir abstrak. Sedang menurut Robinson dan Robinson (Woolfolk dan Nicolich, 1984 : 130), inteligensi didefinisikan sebagai: 1) kapasitas untuk belajar; 2) total pengetahuan yang dicapai seseorang; dan 3) kemampuan beradaptasi secara sukses dengan situasi baru dan lingkungan pada umumnya.

Winkel dan Suryabrata membuat pengelompokkan definisi dengan cara yang berbeda. Menurut Winkel (1996:138), inteligensi dapat diberikan pengertian luas dan sempit. Dalam arti luas, inteligensi adalah kemampuan mencapai prestasi dalam berbagai bidang kehidupan. Sedang dalam arti sempit, inteligensi adalah kemampuan untuk mencapai prestasi di sekolah. Inteligensi dalam pengertian sempit mempunyai pengertian yang sama dengan kemampuan intelektual atau kemampuan akademik. Suryabrata (2002 : 124 - 134) mengelompokkan beragam definisi menjadi lima kelompok, yaitu: 1) Konsepsi yang bersifat spekulatif. Konsepsi ini memandang inteligensi sebagai taraf umum dari sejumlah besar daya khusus; 2) Konsepsi yang bersifat pragmatis. Menurut konsepsi ini, inteligensi adalah apa yang dites oleh tes inteligensi (intelligence is what the tests test); 3) Konsepsi yang didasarkan pada analisis faktor. Menurut konsepsi ini, penyelidikan dan pencarian sifat hakikat inteligensi harus mempergunakan teknik analisis faktor; 4) Konsepsi yang bersifat operasional. Menurut konsepsi ini, faktor-faktor yang mendukung sifat dan hakikat inteligensi sudah diketahui. Pengujian dimaksudkan untuk mencari letak faktor; 5) Konsepsi yang didasarkan pada analisis fungsional. Menurut konsepsi ini, sifat dan hakikat inteligensi disusun berdasarkan bagaimana berfungsinya inteligensi.

\section{Heriditas atau modifikasi}

Perdebatan mengenai inteligensi tidak berhenti dalam definisi. Pandangan mengenai faktor-faktor yang memberi kontribusi terhadap inteligensi juga masih kontroversi. Kontroversi terjadi dalam memandang apakah inteligensi merupakan heriditas yang dibawa secara genetik sejak lahir atau modifikasi dari lingkungan.

Pendapat pertama menyatakan bahwa inteligensi dipengaruhi oleh heriditas. Menurut pandangan ini, inteligensi adalah kemampuan yang dibawa sejak lahir yang memungkinkan seseorang berbuat sesuatu dengan cara tertentu. Waterink (Purwanto, 2003:52) menyatakan bahwa belum dapat dibuktikan bahwa inteligensi dapat diperbaiki atau dilatih. Bukti yang mendukung sifat penurunan inteligensi ditunjukkan oleh Bouchard (Atkinson, Atkinson, Smith dan Bem, 2003:185) dengan mengkorelasikan inteligensi dengan berbagai keterkaitan genetik. Hasil korelasi tersebut disajikan berikut : 
Tabel 1. Korelasi inteligensi dengan berbagai keterkaitan genetik

\begin{tabular}{|l|l|l|}
\hline No & Hubungan & Korelasi \\
\hline 1 & Kembar identik & \\
\hline & a Dibesarkan bersama & 0,86 \\
\hline & b Dibesarkan terpisah & 0,72 \\
\hline 2 & Kembar fraternal & \\
\hline & Dibesarkan bersama & 0,60 \\
\hline 3 & Saudara kandung & \\
\hline & a Dibesarkan bersama & 0,47 \\
\hline & b Dibesarkan terpisah & 0,24 \\
\hline 4 & Orang tua dan anak & 0,40 \\
\hline 5 & Orang tua angkat dan anak & 0,31 \\
\hline 6 & Sepupu & 0,15 \\
\hline
\end{tabular}

Dari data tersebut terlihat adanya hubungan antara heriditas dan inteligensi. Misalnya, anak kembar identik mempunyai korelasi yang lebih tinggi $(0,86)$ dibandingkan anak kembar fraternal $(0,60)$. Orang tua dan anak berkorelasi lebih tinggi $(0,40)$ dibandingkan orang tua angkat dan anak $(0,31)$.

Pendapat kedua menyatakan bahwa inteligensi merupakan hasil modifikasi lingkungan. Pendapat ini didasarkan pada bukti yang ditunjukkan oleh Frohn (Purwanto, 2003:52) bahwa daya pikir anak-anak yang telah mendapat didikan dari sekolah menunjukkan sifat-sifat yang lebih baik daripada anak-anak yang tidak bersekolah. Pendapat bahwa inteligensi dapat dimodifikasi dapat pula diambil dari kesimpulan penelitian Head Start Program (Atkinson, Atkinson, Smith dan Bem, 2003 : 187 - 190). Anak keluarga kurang mampu di AS cenderung tertinggal dalam perkembangan kognitif dan pemerintah menyelenggarakan program yang diberi nama Head Start Program. Guru khusus mengunjungi anak di rumah beberapa kali setiap minggu untuk bermain dengan mereka, melibatkan anak dalam aktivitas menyusun balok, melihat gambar, menyebutkan warna dan sebagainya. Guru memberikan rangsangan intelektual yang biasanya didapatkan anak-anak dari kalangan atas. Hasil dari program, anak-anak yang berperan serta dalam program memiliki nilai yang lebih tinggi pada tes Stanford - Binet atau WISC, lebih percaya diri dan cakap secara sosial dibandingkan anak-anak yang tidak memperoleh perhatian khusus.

Pendapat yang menyatakan bahwa inteligensi merupakan hasil modifikasi juga dihubungkan dengan ras. Menurutnya, tidak terdapat ras yang secara genetik lebih superior dari ras lainnya. Menurut Haviland (1999 : 192), pandangan yang menyatakan bahwa IQ seseorang sampai batas tertentu dapat diwariskan adalah pendapat yang sesat. Tes-tes yang diadakan oleh para peneliti kulit putih untuk orang kulit putih dan hitam sering menunjukkan bahwa orang kulit putih mendapat nilai lebih tinggi. Apa yang diperlihatkan oleh testes itu adalah bahwa dalam situasi sosial tertentu orang kulit putih berprestasi lebih baik daripada orang kulit hitam. Tes tidak mengukur inteligensi tapi mengukur kemampuan orang-orang tertentu yang dibesarkan dalam kebudayaan tertentu untuk menjawab masalah-masalah yang terpengaruh oleh kondisi sosial tertentu. Tes dibuat oleh orang kulit putih mestinya untuk sesama orang kulit putih. Adalah tidak realistis mengharap orang-orang yang tidak terbiasa dengan nilai-nilai dan sifat-sifat orang kulit putih dapat menjawab masalah-masalah yang didasarkan pada kebiasaan-kebiasaan tersebut.

Hasil penelitian mendukung bahwa tidak relevan menghubungkan inteligensi dengan ras. Sebuah penelitian dilakukan di Israel mengenai anak-anak yang tinggal di pemukiman (kibbutzim) (Atkinson, Atkinson, Smith dan Bem, t.th : 190 196). Israel menghadapi masalah adanya perbedaan yang besar pada inteligensi dan latar belakang pendidikan di antara orang Yahudi dari berbagai budaya. Rata-rata kemampuan intelektual Yahudi keturunan Eropa lebih tinggi dibandingkan dengan orang-orang Yahudi dari negara-negara Arab. Dalam program, anak-anak dibesarkan dalam pemukiman tertentu, tidak tinggal dengan orang tuanya, di rumah di bawah pengawasan para wanita yang terlatih khusus mengasuh anak. Hasilnya, inteligensi anak cenderung tidak berhubungan dengan negara asalnya.

\section{Inteligensi : hubungannya dengan bakat, kreativitas, dan prestasi}

Dalam diri manusia terdapat tiga kemampuan yang berhubungan yaitu inteligensi, bakat dan kreativitas. Inteligensi merupakan kemampuan potensial umum (general potential ability). Bakat merupakan kemampuan potensial khusus (specific potential ability). Sedang kreativitas berhubungan dengan kemampuan dan pola mendekati masalah dengan cara yang berbeda. 
Inteligensi berhubungan dengan bakat. Anak yang berbakat adalah anak yang sangat cerdas atau mempunyai inteligensi yang sangat tinggi. Kemampuan intelektual menjadi salah satu ukuran keberbakatan. Menurut Semiawan (1997:24), satu persen dari populasi total penduduk Indonesia yang rentangan IQ 137 ke atas merupakan manusia berbakat tinggi (highly gifted), sedang mereka yang rentang IQ berkisar antara 120 137 merupakan berbakat sedang (moderately gifted). Mereka mempunyai keberbakatan intelektual (academic talented).

Bakat berhubungan dengan kreativitas. Kreativitas telah menjadi dimensi baru untuk mengidentifikasi keberbakatan. Keberbakatan selain mencakup kemampuan intelektual tinggi juga menunjuk pada kemampuan kreatif. Bakat dalam pengertian baru mengandung dimensi kreatif. Menurut Clark, kreativitas merupakan ekspresi tertinggi dari keberbakatan (Semiawan, 1997:50).

Inteligensi sering dihubungkan kreativitas. Orang yang mempunyai IQ tinggi belum tentu kreatif, tapi orang kreatif pasti mempunyai IQ tinggi. Oleh karenanya apabila tes inteligensi digunakan untuk mengidentifikasi anak berbakat, sekitar $70 \%$ anak yang kreativitasnya tinggi ditinggalkan (Morse dan Wingo, 1970:262). Hal itu disebabkan karena kreativitas berhubungan dengan IQ tapi tes IQ tidak secara langsung mengukur kreativitas (Good dan Brophy, 1990 : 617). Terman (Guilford, 1971:138 - 139) menunjukkan bukti bahwa tes inteligensi tidak mampu mendiskriminasikan kreativitas. Dia melakukan penelitian atas tujuh orang anak yang pandai dan tujuh orang anak yang bodoh. Hasil penelitiannya menyimpulkan bahwa anak yang mempunyai IQ tinggi dapat memperoleh hasil yang tinggi atau rendah dalam tes produksi divergen. Dengan dasar ini maka kemampuan produksi divergen telah keluar dari domain tes dan konsep inteligensi. Oleh karenanya, kreativitas sebagai salah satu dimensi keberbakatan harus dicari di luar batasan IQ.

Banyak ahli sepakat bahwa inteligensi berhubungan dengan prestasi. Oleh karenanya variasi dalam prestasi dapat diramalkan berdasarkan variasi dalam inteligensi. Menurut Barrett dan Depinet (Atkinson, Atkinson, Smith dan
Bem, t.th: 167), nilai tes inteligensi sangat berkorelasi dengan berbagai parameter prestasi akademik (nilai, kelangsungan di sekolah, kemungkinan lulus, dan sebagainya). Anak yang mencapai nilai lebih tinggi pada tes seperti Stanford-Binet dan Wechler Intelligence Scale mendapatkan nilai yang lebih baik, lebih menikmati sekolah, lebih mampu mengikuti pelajaran di sekolah, dan dalam kehidupan selanjutnya cenderung mendapatkan keberhasilan kerja yang lebih besar.

Walaupun inteligensi berhubungan dengan prestasi, inteligensi hanya salah satu faktor yang menentukan prestasi. Faktor inteligensi akan dapat meramalkan lebih baik prestasi apabila dilakukan bersama faktor lain. Menurut Purwanto (2003:59), inteligensi memberi kemungkinan untuk berkembang. Kemungkinan dapat direalisasikan tergantung pula kepada pribadi dan kesempatan yang ada.

\section{Perkembangan teori inteligensi}

Beberapa ahli mencoba memberikan penjelasan teoretik mengenai inteligensi. Beberapa di antara mereka adalah Lewis Terman, Charles Spearman, Sternberg, Louis L Thurstone, JP Guilford dan Howard Gardner. Teori-teori mereka dapat dijelaskan berikut.

1. Lewis Terman (1900)

Terman melanjutkan kerja yang dilakukan oleh Binet dalam melakukan pengukuran inteligensi dengan mempertahankan konsep Binet mengenai usia mental. Menurut Terman, inteligensi merupakan satu kemampuan tunggal yang disebut usia mental (mental age). Usia mental adalah kemampuan yang seharusnya dimiliki ratarata anak pada usia tertentu. Dia mendefinisikan inteligensi sebagai kemampuan untuk berpikir abstrak (Winkel, 1996:139). Dia yakin bahwa inteligensi merupakan faktor tunggal yang merupakan kemampuan individu dalam verbalisasi dan berpikir abstrak. Menurut Thornburg (1984: 179), inteligensi merupakan monogenetik karena didasarkan pada faktor umum tunggal (general, disingkat $g$ ) yang diwarisi.

Di samping usia mental, dikenal pula konsep usia kronologis (chronological age). Usia kronologis adalah usia anak menurut perhitungan kalender. Ukuran inteligensi (intelligence quotient) 
merupakan rasio perbandingan antara usia mental dengan usia kronologis. Jika inteligensi diberikan notasi dengan IQ, usia mental dengan MA dan usia kronologis dengan CA, maka dapat disajikan rumus perhitungannya berikut :

$$
I Q=\frac{M A}{C A}
$$

Dari rumus di atas diketahui bahwa pada anak yang mempunyai inteligensi normal maka $M A=$ CA atau MA sama dengan MA rata-rata anak seusianya. Anak yang mempunyai MA > CA mempunyai inteligensi di atas rata-rata, dan anak yang mempunyai $\mathrm{MA}<\mathrm{CA}$ mempunyai inteligensi di bawah rata-rata.

\section{Charles Spearman (1927)}

Menurut Spearman, inteligensi bukanlah kemampuan tunggal, melainkan terdiri dari dua faktor, sehingga teorinya dikenal sebagai teori inteligensi dwifaktor atau bifaktor. Kecerdasan dapat dibagi menjadi dua yaitu kecerdasan umum (general ability) dan kecerdasan khusus (specific ability), sehingga inteligensi mempunyai dua faktor. Dua faktor itu adalah faktor yang bersifat umum (general factor, disingkat g) dan yang bersifat khusus (specific factor, disingkat s). Faktor umum mendasari semua tingkah laku, sedang faktor khusus hanya mendasari tingkah laku tertentu. Menurut Suryabrata (2002:128), faktor umum bergantung kepada keturunan dan faktor khusus bergantung kepada pengalaman (lingkungan, pendidikan).

Setiap masalah dipecahkan menggunakan kombinasi antara inteligensi umum dan spesifik. Menurut Winkel (1996:139), inteligensi adalah hasil perpaduan antara faktor umum dan sejumlah faktor khusus. Perpaduan faktor $\mathrm{g}$ dan $\mathrm{s}$ bersifat unik untuk setiap orang, sehingga ada perbedaan individu satu sama lain. Menurut Spearman (Atkinson, Atkinson, Smith dan Bem, t.th:174), semua individu memiliki faktor inteligensi umum (g) dalam jumlah yang bervariasi. Seseorang dapat dikatakan secara umum cerdas atau bodoh tergantung pada jumlah $\mathrm{g}$ yang ia miliki. Faktor $\mathrm{g}$ merupakan determinan utama kemampuan mengerjakan soal tes inteligensi.

\section{Sternberg (1931)}

Menurut Sternberg inteligensi mempunyai tiga bagian sehingga teorinya dikenal dengan teori inteligensi triarkhis. Tiga bagian inteligensi itu adalah konseptual, kreatif dan kontekstual (Good dan Brophy, 1990: 597). Pertama, konseptual adalah komponen pemrosesan informasi yang digunakan dalam inteligensi. Menurut Winkel (1996 : 140), bagian konseptual mempunyai tiga fungsi yaitu komponen pengatur dan pengontrol (metacomponent atau metacognition), komponen pelaksanaan (performance) dan komponen untuk memperoleh informasi baru (knowledge acquisition). Kedua, kreatif merupakan kemampuan seseorang untuk menghadapi tantangan baru secara efektif dan mencapai taraf kemahiran dalam berpikir sehingga mudah berhasil mengatasi segala permasalahan yang muncul. Ketiga, kontekstual adalah kemampuan untuk menempatkan diri dalam lingkungan yang memungkinkan akan berhasil, menyesuaikan diri dengan lingkungan dan mengadakan perubahan terhadap lingkungan bila perlu, misalnya memilih kasus, menyesuaikan dengan lingkungan kerja baru dan kelincahan pergaulan sosial.

\section{Louis L Thurstone (1938)}

Thurstone memandang inteligensi bersifat multifaktor. Faktor-faktor yang membentuk inteligensi adalah faktor umum (common factors, disingkat c) dan faktor khusus (specific factors). Faktor umum terdiri dari tujuh faktor yang membentuk perilaku tertentu yang bersifat umum. Faktor khusus adalah faktor-faktor yang mendasari perilaku yang bersifat khusus. Menurut Suryabrata (2002:129), tingkah laku dibentuk oleh dua faktor yaitu faktor umum (c) dan faktor khusus (s). Faktor c sebanyak tujuh macam, sedang faktor s sebanyak tingkah laku khusus yang dilakukan oleh manusia yang bersangkutan.

Menurut Thurstone, tidak ada faktor g seperti dalam teori Spearman. Kemampuan umum bukanlah faktor $\mathrm{g}$ melainkan kombinasi faktorfaktor c. Faktor c adalah kemampuan mental utama (primary mental abilities) yang merupakan kombinasi dari tujuh faktor umum. Oleh karenanya teori Thurstone kadang dikenal sebagai teori kemampuan mental utama (primary mental abilities theory). Menurut Anastasi dan Urbina (1997: 
312 - 313) faktor meliputi : (1) penalaran verbal (verbal comphrehension, disingkat $\mathrm{V}$ ), kelacaran kata (word fluency, disingkat W), angka (number, disingkat $\mathrm{N}$ ), ruang (space, disingkat $\mathrm{S}$ ), memori asosiatif (associative memory, disingkat M), kecepatan perseptual (perceptual speed, disingkat $P$ ), dan induksi atau penalaran umum (general reasoning, disingkat $\mathrm{R}$ ).

\section{JP Guilford (1967)}

Menurut Guilford, faktor yang membentuk inteligensi bukan hanya satu faktor (Terman), dua faktor (Spearman), tiga faktor (Sternberg) atau tujuh faktor (Thurstone), melainkan 120 faktor. Berdasarkan analisis faktor, Guilford mengusulkan model berbentuk kubus yang disebut model struktur intelektual dengan 120 faktor.

Sejumlah 120 faktor itu merupakan kombinasi dari tiga dimensi. Ketiga dimensi inteligensi itu adalah dimensi operasi/proses, dimensi isi/materi/ konten, dan dimensi hasil/produk (Guilford, 1971: 61 - 62). Operasi mempunyai lima faktor yaitu kognisi, memori, berpikir konvergen, berpikir divergen dan evaluasi. Konten mempunyai empat faktor yaitu figural, simbolik, semantik dan perilaku. Sedang produk mempunyai enam faktor yaitu unit, kelas, hubungan, sistem, transformasi dan implikasi. Secara keseluruhan inteligensi mempunyai $5 \times 4 \times 6=120$ faktor.

\section{Howard Gardner (1983)}

Menurut Gardner, inteligensi bukanlah satu kemampuan sebagaimana disampaikan oleh Terman, Spearman, Sternberg, Thurstone, dan Guilford. Inteligensi merupakan kemampuan ganda (multiple intelligence). Kemampuan ganda dalam konsep inteligensi menurut Gardner, terdiri dari sembilan kemampuan (Suparno, 2004: 19). Kesembilan kemampuan itu adalah (1) linguistik, (2) matematis - logis, (3) ruang, (4) kinestetik badani, (5) musikal, (6) interpersonal, (7) intrapersonal, (8) lingkungan / naturalis, dan (9) eksistensial.

Masing-masing kemampuan dalam inteligensi menurut Gardner bersifat independen. Gardner (Good dan Brophy, 1990: 595) menyatakan bahwa inteligensi bukanlah tunggal tetapi jamak, yang masing-masing penting untuk bidangnya dan independen satu sama lain. Tiap-tiap kemampuan bersifat independen. Menurut Atkinson, Atkinson, Smith dan Bem (2003: 181), tiap inteligensi merupakan "modul terbungkus" di dalam otak yang bekerja menurut aturan dan prosedurnya sendiri. Cedera otak tertentu dapat mengganggu salah satu jenis inteligensi dan tidak memiliki pengaruh pada inteligensi lain. Independensi kemampuan-kemampuan juga dijelaskan oleh Winkel (1996:140). Menurutnya, independensi kemampuan didasarkan adanya bukti: (1) kerusakan otak pada bagian tertentu tidak mengakibatkan gangguan pada bagian lain, (2) orang sering menyolok pada suatu inteligensi tapi tidak pada inteligensi yang lain.

\section{Pengukuran inteligensi}

Pengukuran inteligensi adalah prosedur pengukuran yang meminta peserta untuk menunjukkan penampilan maksimum, sehingga pengukuran inteligensi dilakukan menggunakan tes yang dikenal dengan tes inteligensi. Tes inteligensi awalnya dikembangkan oleh Sir Francis Galton. Dia tertarik dengan perbedaan individu dari teori evolusi Charles Darwin.

Dilihat dari segi pelaksanaannya tes inteligensi dapat dibedakan menjadi dua macam yaitu tes individual dan kelompok. Termasuk dalam tes individual adalah skala Stanford-Binet dan Wechler. Tes kelompok diberikan kepada sejumlah siswa dengan jawaban tertulis. Tes ini pertama kali digunakan di Amerika Serikat selama Perang Dunia I berupa Army Alpha Test dan Army Beta Test. Army Alpha Test digunakan untuk menyeleksi calon prajurit yang dapat membaca, menulis dan berbahasa Inggris. Army Beta Test digunakan untuk menyeleksi calon prajurit yang buta huruf dan tidak bisa berbahasa Inggris (Abror, 1993: 53 - 57).

Inteligensi diramalkan berhubungan dengan prestasi, baik dalam kehidupan maupun di sekolah. Oleh karenanya prestasi yang hendak diramalkan oleh tes inteligensi dapat bersifat umum dan khusus. Prestasi umum adalah keberhasilan hidup secara umum. Secara khusus prestasi adalah prestasi dalam bidang tertentu di sekolah, misalnya matematika, bahasa, dan sebagainya. Oleh karenanya Winkel (1996:142) membagi tes inteligensi menjadi tes inteligensi umum (general ability test) dan tes inteligensi 
khusus (specific ability test). Tes inteligensi umum terdiri dari butir soal dalam berbagai bidang penggunaan seperti bahasa, bilangan, ruang, dan sebagainya. Tes inteligensi khusus mengarah untuk menyelidiki siswa yang mempunyai bakat khusus dalam bidang studi tertentu seperti bahasa, matematika, dan sebagainya. Tes-tes inteligensi biasanya mengacu pada konsep inteligensi sebagai inteligensi umum. Terdapat bermacam-macam tes inteligensi yang dapat digunakan, di antaranya tes Stanford-Binet dan Wechler.

Tes pertama yang merupakan tes inteligensi moderen dikembangkan oleh ahli psikologi Perancis Alfred Binet pada tahun 1881. Pada saat itu pemerintah Perancis mengeluarkan Undangundang yang mewajibkan semua anak masuk sekolah. Pemerintah meminta Binet untuk membuat tes guna mendeteksi anak-anak yang terlambat intelektualnya (Atkinson, Atkinson, Smith dan Bem, t.th: 152). Tes-tes inteligensi kemudian banyak mengacu pada tes yang telah dikembangkan oleh Binet. Tes inteligensi Binet mengalami beberapa kali revisi. Revisi terakhir adalah revisi yang dikerjakan bersama Terman dari Universitas Stanford yang dikenal dengan tes inteligensi Stanford-Binet. Tes terdiri dari 17 subtes yang dikelompokkan dalam empat area teoretik yaitu penalaran verbal, penalaran kuantitatif, penalaran abstrak-visual, dan ingatan jangka pendek (Good dan Brophy, 1990: 588).

Wechler menyusun tes inteligensi karena beberapa kelemahan yang terdapat pada tes intekegensi Stanford-Binet. Kelemahan itu: 1) tes Stanford-Binet tidak dapat digunakan untuk mengukur inteligensi orang dewasa; 2) tes Stanford-Binet terlalu tergantung pada kemampuan bahasa (Atkinson, Atkinson, Smith dan Bem, t.th: 157). Wechler menyusun tiga tes inteligensi yaitu 1) the Wechler Preschool and Primary Scale of Intelligence (WPPI). Tes ini digunakan untuk mengukur inteligensi anak prasekolah atau pada umur 4 - 5 tahun, 2) the Wechler Intelligence Scale for Children (WISC). Tes ini digunakan untuk mengukur inteligensi anak-anak umur 5 - 15 tahun, dan 3) the Wechler Adult Intelligence Scale (WAIS). Tes ini digunakan untuk orang dewasa di atas umur 15 tahun. Menurut Abror (1993: 56), skala Wechler dibagi menjadi dua kelompok subtes yaitu tes verbal dan tes perbuatan (performance). Tes verbal terdiri dari enam macam yaitu tes informasi, tes pemahaman umum, tes penalaran berhitung, tes analogi, tes lamanya mengingat angka, dan tes perbendaharaan kata sebanyak 40 buah kata yang disusun menurut urutan kesulitan. Tes perbuatan terdiri dari lima macam yaitu tes simbol-angka yang meminta subjek untuk menjodohkan simbol dengan angka, tes menyempurnakan gambar, tes potongan balok, tes menyusun gambar, dan tes pemasangan objek.

Inteligensi ditetapkan dalam ukuran yang disebut intelligence quotient (IQ). Ukuran IQ adalah nisbah atau rasio antara umur kecerdasan (mental age, disingkat MA) dengan umur kalender (chronological age, disingkat CA) (Suryabrata, 2002 : 152). MA diperoleh dari tes psikologi dan $C A$ dihitung dari tanggal kelahiran peserta tes. IQ dihitung dengan rumus berikut :

$$
I Q=\frac{M A}{C A} x 100
$$

IQ dapat dihitung dengan langkah-langkah: (1) menghitung CA. CA dihitung atas dasar kartu kelahirannya, (2) menghitung MA. MA dihitung dengan memberikan terlebih dulu tes inteligensi. Awalnya tes diberikan dengan tes untuk umur yang paling rendah (paling mudah), bertahap makin sukar sampai testi tidak dapat menyelesaikan sama sekali, (3) menghitung IQ menggunakan rumus. Cara perhitungan IQ dapat diberikan contohnya sebagai berikut.

Seorang anak bernama A berumur 5 tahun mengikuti tes inteligensi yang terdiri dari enam butir soal tes inteligensi. Hasil yang diperoleh $A$ dalam tes disajikan dalam tabel berikut:

Tabel 2. Contoh hasil uji inteligensi

\begin{tabular}{|c|c|c|c|c|c|c|}
\hline \multirow{2}{*}{$\begin{array}{l}\text { Butir untuk } \\
\text { umur }\end{array}$} & \multicolumn{6}{|c|}{ Butir ke } \\
\hline & 1 & 2 & 3 & 4 & 5 & 6 \\
\hline $3 ; 0$ & $x$ & $x$ & $x$ & $\mathrm{x}$ & $x$ & $\mathrm{x}$ \\
\hline $4 ; 0$ & $x$ & $x$ & $x$ & $\mathrm{x}$ & $x$ & $\mathrm{x}$ \\
\hline $5 ; 0$ & $x$ & $x$ & $x$ & $\mathrm{X}$ & $x$ & $x$ \\
\hline $6 ; 0$ & $x$ & $x$ & $x$ & $x$ & $x$ & $x$ \\
\hline $7 ; 0$ & $x$ & $x$ & $x$ & - & - & - \\
\hline $8 ; 0$ & - & - & - & - & - & - \\
\hline
\end{tabular}

Keterangan : butir dapat dijawab benar $(x)$, butir tidak dapat dijawab (-). 
Dari data tersebut inteligensi $A$ dapat dihitung sebagai berikut: (1) $C A=5$ tahun, (2) $M A=6$ tahun $+3 / 6$ tahun $=6,5$ tahun, (3) IQ $=(\mathrm{MA} / \mathrm{CA}) \times 100=$ $(6,5 / 5) \times 100=130$.

IQ dapat diinterpretasikan dengan membandingkan antara CA dengan MA. Individu dengan inteligensi normal mempunyai MA yang sama dengan CA. Mereka yang mempunyai MA di atas CA mempunyai inteligensi di atas rata-rata, sedang yang mempunyai MA di bawah CA mempunyai inteligensi di bawah rata-rata.

IQ juga dapat diinterpretasikan dengan membandingkan dengan skor kelompok norma. Asumsinya, pada populasi, inteligensi mempunyai distribusi normal. Pada sampel yang representatif, inteligensi mempunyai distribusi normal sebagaimana populasinya. Sebagai sebuah distribusi normal, inteligensi dapat dibagi-bagi dalam daerah-daerah kurva normal. Skor seseorang dalam tes inteligensi dapat diinterpretasikan mengacu kepada daerah-daerah dalam kurva normal. Penggolongan daerah-daerah dapat mengikuti klasifikasi IQ yang dibuat oleh Woodworth dan Marquis (Suryabrata, 2002 : 157) sebagai berikut:

Tabel 3. Klasifikasi IQ

\begin{tabular}{|l|l|}
\hline Skor IQ & Kategori \\
\hline Di atas 140 & Luar biasa (genius) \\
\hline $120-139$ & Cerdas sekali ( very superior) \\
\hline $110-119$ & Cerdas (superior) \\
\hline $90-109$ & Sedang (average) \\
\hline $80-89$ & Bodoh (dull average) \\
\hline $70-79$ & Anak pada batas (border line) \\
\hline $50-69$ & Debil (moron) \\
\hline $30-49$ & Ambisil (embicile) \\
\hline Di bawah 30 & Ideot \\
\hline
\end{tabular}

\section{Simpulan dan saran}

\section{Simpulan}

Belum ada kesepakatan tentang definisi inteligensi. Inteligensi dapat diberikan arti sempit dan luas. Dalam arti sempit, inteligensi adalah prestasi di sekolah. Dalam arti luas, inteligensi adalah prestasi dalam berbagai bidang kehidupan.

Kesepakatan juga belum diperoleh mengenai faktor-faktor yang memberi kontribusi terhadap inteligensi. Beberapa hasil penelitian menunjukkan bahwa inteligensi diperoleh secara heriditas, namun beberapa hasil penelitian lain juga menunjukkan bahwa inteligensi dapat dimodifikasi. Banyak yang sepakat bahwa inteligensi merupakan kombinasi antara heriditas dan modifikasi.

Inteligensi berhubungan dengan bakat, kreativitas dan prestasi. Inteligensi berhubungan dengan bakat karena anak yang berbakat adalah anak dengan inteligensi sangat tinggi. Inteligensi berhubungan dengan kreativitas walaupun kreativitas tidak dapat diidentifikasi menggunakan tes inteligensi. Inteligensi juga berhubungan dengan prestasi. Variasi dalam prestasi dapat diramalkan dari variasi dalam inteligensi.

Teori inteligensi terus mengalami perkembangan. Perkembangan teori dimulai dari Lewis Terman, Charles Spearman, Sternberg, Lewis L Thurstone, James P Guilford hingga Howard Gardner.

Inteligensi diukur menggunakan tes inteligensi. Ukuran yang biasa digunakan adalah IQ sehingga tes inteligensi biasa dikenal sebagai tes IQ. Ukuran IQ adalah rasio antara umur kecerdasan dengan umur kalender.

\section{Saran}

Meski para ahli tidak sepakat mengenai konsep inteligensi, namun mereka sepenuhnya sepakat bahwa inteligensi merupakan konsep yang penting untuk dipahami, khususnya dalam dunia pendidikan. Pemahaman yang baik mengenai inteligensi akan membantu memberikan pelayanan yang optimal dalam pendidikan. Oleh karenanya kajian mengenai inteligensi sangat penting untuk terus dikembangkan.

Kepentingan untuk melakukan kajian mengenai inteligensi berhubungan dengan usaha memahami konsep dan cara pengukurannya. Pengukuran inteligensi yang memadai memang masih menyisakan kontroversi karena sulitnya diperoleh kesepahaman dalam konsep. Konsep yang berbeda akan menghasilkan perbedaan dalam cara melakukan pengukurannya. Cara pengukuran inteligensi akan terus berkembang sejalan perkembangan konsepnya.

Meski belum diperoleh kesekatan dalam cara mengukur inteligensi, mengingat pentingnya peranan inteligensi dalam pendidikan, maka 
usaha-usaha untuk mengidentifikasi inteligensi harus dilakukan melalui proses pengukuran. Hal itu diperlukan agar data inteligensi mempunyai landasan yang kuat.

\section{Pustaka Acuan}

Abror, Abd Rachman. 1993. Psikologi pendidikan. Yogyakarta: PT Tiara Wacana

Anastasi, Anne dan Urbina, Susana. 1997. Psychological testing. Seventh edition. Upper Saddle River, NJ: Prentice Hall, Inc

Atkinson, Rita L; Atkinson, Richard C; Smith, Edward E dan Bem, Daryl J. 2003. Pengantar psikologi. Terjemahan oleh Widjaja Kusuma. Batam Centre: Interaksara

Good, Thomas L dan Brophy, Jere E. 1990. Educational psychology a realistic approach. New York: Longman

Guilford, JP. 1971. The nature of human intelligence. London: McGraw Hill

Haviland, William A. 1999. Antropologi. Terjemahan oleh RG Sukidjo. Edisi keempat. Jilid 1. Jakarta: Penerbit Erlangga

Morse, William C dan Wingo, G Max. 1970. Psychology and teaching. Glenview, Illinois: Scott, Foresman and Company

Purwanto, M Ngalim. 2003. Psikologi pendidikan. Bandung: PT Remaja Rosdakarya

Semiawan, Conny. 1997. Perspektif pendidikan anak berbakat. Jakarta: PT Gramedia Widiasarana Indonesia

Sukmadinata, Nana Syaodih. 2003. Landasan psikologi proses pendidikan. Bandung: PT Remaja Rosdakarya

Suparno, Paul. 2004. Teori inteligensi ganda dan aplikasinya di sekolah. Yogyakarta: Penerbit Kanisius

Suryabrata, Sumadi. 2002. Psikologi pendidikan. Jakarta: PT Raja Grafindo Persada

Thornburg, Hershel D. 1984. Introduction to educational psychology. St Paul: West Publishing Company Winkel, WS. 1996. Psikologi pengajaran. Jakarta: PT Gramedia Widiasarana Indonesia

Woolfolk, Anita E dan Nicolich, Lorraine McCune (1984). Educational psychology for teachers. Englewood Cliffs, New Jersey: Prentice Hall Inc 